\title{
Examining the Relationship between Digital Game Preferences and Computational Thinking Skills
}

\author{
Hatice Yildiz Durak, Fatma Gizem Karaoglan Yilmaz, Ramazan Yilmaz \\ Bartin University, Turkey
}

\begin{abstract}
The purpose of this study is to identify whether computational thinking skills among secondary school students differ depending on the type of digital games they play. The participants of this study were 202 secondary school students at $5^{\text {th }}, 6^{\text {th }}, 7^{\text {th }}$ and $8^{\text {th }}$ grades during 2016-2017 academic year. Correlational survey method was used during this study. Furthermore, there were three different data collection instruments used. The first one was "Personal Information Form". The second one was "Computational Thinking Skills Scale" and the third data collection instrument was "Questionnaire for Type of Games Played with Digital Tools". Results indicated that students scored higher compared to other sub-scales while their scores from the critical thinking sub-scale was the lowest. The most frequently played game category of the students was found to be dress up/make-up games.
\end{abstract}

Keywords: Computational thinking; Digital game types; Digital game preferences; Secondary school students

\section{Introduction}

Rapid developments in the field of technology in the $21^{\text {st }}$ century have led to its intensified use by children. In addition to that, advanced technologies have changed the needs of societies and which has thus reflected on the skills individuals are expected to have. Recently popular computational thinking involves understanding the problem, producing solutions, thinking patterns related to abstraction and presentation. Computational thinking, which is significant among the $21^{\text {st }}$ century skills, includes such basic skills as algorithmic thinking and problem solving, which are expected from the individuals of this century (Wing, 2006). According to The International Society for Technology in Education (ISTE) (2015) computational thinking develops the creativity and critical thinking skills in order to improve their problem solving skills of individuals through the use of computers. Computational thinking, which is a popular concept today, has become a topic of interest for researchers in all areas of learning with the view that claims "thinking involves attitudes and behaviors not only computer scientists but everyone could have". There are different views about definitions of the concept of computational thinking and its scope (Barr \& Stephenson, 2011; Brennan \& Resnick, 2012; Grover \& Pea, 2013). According to Wing (2006), computational thinking includes "understanding the problem, finding solutions, thinking patterns related to abstraction and presentation". ISTE (2015) defines computational thinking skills as a reflection of various skills such as algorithmic thinking, creative thinking, logical thinking and problem solving. Therefore, it is emphasized that computational thinking has a multi-dimensional structure. The National Research Council (NRC) (2012) sees mathematics and computational thinking as basic practices within the scope of $\mathrm{K}-12$ science 
education. In the light of these given definitions, it can be stated that computational thinking is related to various factors. One of these factors is the digital games. It is indicated that computer games could be an effective way to the develop problem solving skills of students (Boyle, Connolly, \& Hainey, 2011). This is because computer games encourage practicing problem solving approaches by offering problems in authentic environments and thus, they improve learning in considerable terms (Kim, Park, \& Baek, 2009). What is more, it can also be stated that games have a significant impact on learning experiences. In many studies, (Chen, Wigand, \& Nilan, 1999; Hoffman \& Novak, 1996) it is emphasized that such indispensable features of digital games as setting strategies, focused attention and struggling improve problem solving, reflective and algorithmic thinking. Due to the given reasons and its impact on learning, it is highlighted that computer games are increasingly becoming important tools to develop problem solving skills in various learning areas in education and could be used towards this objective (Lee \& Chen, 2009; Papastergiou, 2009; Shih, Shih, Shih, Su \& Chuang, 2010; Tan \& Biswas, 2007).

Examining this topic, it appears that games played via digital tools have a significant user group among the K-12 age group, that these games have replaced traditional games in recent years and have become the most frequently preferred free time activities (Connolly, Boyle, MacArthur, Hainey, \& Boyle, 2012). Although studies regarding digital games focus on certain negative effects of these games such as violence, aggression, addiction, social behavioral disorders (Anderson \& Bushman, 2001; Griffiths, Davies, \& Chappell, 2004; Ogletree \& Drake, 2007) there are findings highlighting positive effects of playing digital games (Ferguson, 2007). In fact, there are results indicating that digital games are motivating, interesting and develop problem solving skills (Subrahmanyam \& Greenfield, 1994) which strengthen the view that the advantages of these games could be associated with education (Freitas, 2006).

It is claimed that digital games are effective in improving the problem solving, creativity and reflective thinking skills of the individuals with its features such as enabling individuals to have active experiences, providing solutions in problem-based environments and offering instant feedback (Boyle, Connolly, \& Hainey, 2011). There are numerous discussions supporting and opposing the use of digital games in these ways.

Computer games affect problem solving skills of students (Connolly, Stansfield, \& Hainey, 2008) and could be an effective approach towards providing support for developing computational thinking because both computer games and computational thinking skills address problem solving activity in authentic contexts. In addition, games encourage students to utilize their reasoning, algorithmic, reflective thinking and problem solving skills in authentic contexts (Kim, Park, \& Baek, 2009) and thus could improve computational thinking. The relationships of this situation is presented in Table 1.

Table 1. Examples of Game Activities Related to Different Features of CT

\begin{tabular}{l|l|l|l}
\hline Task & $\begin{array}{l}\text { Associated CT } \\
\text { skill category }\end{array}$ & Game activity & Rationale of the skill category \\
\hline $\begin{array}{l}\text { Problem } \\
\text { identification } \\
\begin{array}{l}\text { and } \\
\text { decomposition }\end{array}\end{array}$ & Problem Solving & $\begin{array}{l}\text { Help the robot to } \\
\text { reach the teleporter. } \\
\text { Activate robot's light } \\
\text { when robot stands on } \\
\text { the teleporter }\end{array}$ & $\begin{array}{l}\text { CT is described as a problem solving } \\
\text { approach in various studies (Wing, } \\
\text { 2006; Guzdial 2008). In conjunct to } \\
\text { this, Schell (2008) explains the idea of } \\
\text { what a game is as "a problem solving } \\
\text { activity, approached with a playful } \\
\text { attitude." }\end{array}$ \\
\hline
\end{tabular}




\begin{tabular}{|c|c|c|c|}
\hline $\begin{array}{l}\text { Creating } \\
\text { efficient and } \\
\text { repeatable } \\
\text { patterns }\end{array}$ & $\begin{array}{l}\text { Building } \\
\text { Algorithms }\end{array}$ & $\begin{array}{l}\text { Create a solution } \\
\text { algorithm to complete } \\
\text { all levels with as few } \\
\text { slots as possible. Use } \\
\text { functions to create } \\
\text { repeatable patterns. }\end{array}$ & $\begin{array}{l}\text { Perkovic et al. (2010) describe } \\
\text { computation as "the execution of } \\
\text { algorithms that go through a series of } \\
\text { stages until a final state is reached." }\end{array}$ \\
\hline $\begin{array}{l}\text { Practicing } \\
\text { debug-mode }\end{array}$ & Debugging & $\begin{array}{l}\text { Press the debug button } \\
\text { to monitor your } \\
\text { solution algorithm to } \\
\text { detect any potential } \\
\text { errors in your logic. }\end{array}$ & $\begin{array}{l}\text { Wing (2006) describes "debugging" as } \\
\text { an essential component of both CT } \\
\text { and programming. }\end{array}$ \\
\hline $\begin{array}{l}\text { Practicing } \\
\text { runtime mode }\end{array}$ & Simulation & $\begin{array}{l}\text { Observe the } \\
\text { movements of your } \\
\text { robot during the run- } \\
\text { time. Can you follow } \\
\text { your solution } \\
\text { algorithm? Do you } \\
\text { observe the expected } \\
\text { behaviours? }\end{array}$ & $\begin{array}{l}\text { Moursund (2009) reports that "the } \\
\text { underlying idea in computational } \\
\text { thinking is developing models and } \\
\text { simulations of problems." }\end{array}$ \\
\hline Brainstorming & Socializing & $\begin{array}{l}\text { Examine the winning } \\
\text { strategies of other } \\
\text { players. Compare their } \\
\text { solutions with yours. } \\
\text { What advice would } \\
\text { you give yourself and } \\
\text { to them for scoring } \\
\text { better in the game? } \\
\text { Discuss. }\end{array}$ & $\begin{array}{l}\text { Berland \& Lee (2011) refers social } \\
\text { perspective of computational thinking } \\
\text { as "distributed computation in which } \\
\text { different pieces of information or logic } \\
\text { are contributed by different players } \\
\text { during the process of debugging, } \\
\text { simulation or algorithm building." }\end{array}$ \\
\hline
\end{tabular}

Source: Kazimoglu, C., Kiernan, M., Bacon, L., \& MacKinnon, L. (2012).

It can be said that there is a relationship between computational thinking skills and the structure of digital games. However, when the literature is reviewed, there are no studies found examining the relationship between digital game preferences and computational thinking skills. Hence, there appears to be a gap within the literature regarding this topic. On the other hand, computational thinking skills are one of the 21st century skills and is considered to be essential in our present day. It is therefore necessary to examine the relationship of this ability with different variables. This study looks into the relationships between computational thinking skills and the preferred game types and while attempting to provide a different perspective to the development of these skills.

In the light of the above mentioned reasons, this study also aims to determine whether computational thinking skills of the secondary school students differ based on the digital games they play. In this respect, this analysis was guided by the following research questions:

- What is the level of computational thinking skills among students?

- Which type of digital games do students prefer?

- Is there a statistically significant different in,

○ Computational thinking skill levels

- Creativity levels 
- Algorithmic thinking levels

- Collaboration levels

- Critical thinking levels

- Problem solving levels of the students based on the type of digital games they prefer?

\section{Method}

\section{Research Model}

This study is a survey study as it tries to identify the types of games secondary school students play and their computational thinking levels; and correlational study as it looks into the relationships between these variables. A survey aims to define a current case or one that existed in the past as they exist. The case, individual or object that is the subject of the study is defined in its own conditions and as they exist. There is no effort to change or affect them (Karasar, 2015). Correlational surveys, on the other hand, aim to determine whether there is a change among two or more variables and/or the degree of the change (Karasar, 2015).

\section{Participants of the Study}

The participants of this study were 202 students studying at secondary school $\left(5^{\text {th }}, 6^{\text {th }}, 7^{\text {th }}\right.$ and $8^{\text {th }}$ grades) during 2016-2017 academic year. The participants were voluntary students from the schools which were chosen using convenient sampling method. Participants take Information technologies class. The ages of the participants ranged between 11 and 15 . Of them, $58 \%$ were female students and $42 \%$ were male students.

\section{Data Gathering Instruments}

In terms of data gathering instruments, three data collection instruments were used during this study. The first one was "Personal Information Form", the second one was "Computational Thinking Skills Scale" and the third one was "Questionnaire for Type of Games Played with Digital Tools".

Personal Information Form was developed by the researchers. It was a questionnaire that included 10 questions, and through these questions, personal information of the participants as well as information about access to information technologies and to what extent they use these technologies were collected. The type of items of the questionnaire differed in each item but mainly the questions were Likert type questions.

The second data collection instrument used in the study was Computational Thinking Skills Scale. The scale, which was originally developed by Korkmaz, Cakir and Ozden (2015), included 22 items in five sub-scales and it was a Likert-type scale. There were five sub-scales; "Creativity", "Algorithmic Thinking", "Cooperativity" and "Critical Thinking" sub-scales had four items each, while "Problem Solving" sub-scale had six items. The Cronbach alpha reliability coefficient found for the scale in this study was high .92 . 
The third data collection instrument used in the study was Questionnaire for Type of Games Played with Digital Tools and it was developed by the researchers. In this data collection tool, participants were asked to indicate the games they play most often in digital tools (computers, mobile phones, tablets etc.).

\section{Data Collection Procedures}

The data collection was conducted using an online questionnaire in a face-to-face environment. While administering the questionnaire, participants were first informed about the study. Later, the link to the online questionnaire was given to the participants to answer the questions. In the process of administering the questionnaires, researchers first informed teachers to solve any problems that could arise while administering the questionnaires.

Data collection instruments were administered in the Information Technologies (IT) labs of the secondary schools of the Ministry of Education. The questionnaires were administered by Information Technologies teachers with the approval of the school principals. In order to achieve this, the IT teachers were first contacted and the schools where IT teachers admitted to provide support to the study were chosen. The administration of the questionnaires was carried out during IT classes.

\section{Data Analysis}

The data were analyzed using non-parametric statistical techniques, Kruskal Wallis test and information on frequency, percentages, minimum and maximum values are given depending on the research question. Significance level was set as .05 for the analysis of the data.

\section{Findings}

\section{Students Computational Thinking Skill Levels}

In order to determine computational thinking skills levels of students, the arithmetic means and standard deviations of the data collected via Computational Thinking Skills Scale were presented in Table 2.

Table 2. Students' Computational Thinking Skills Levels

\begin{tabular}{lcccc}
\hline Subscales & $\bar{X}$ & SD & Min & Max \\
\hline CT & 3.55 & .72 & 1.05 & 5.00 \\
\hline Creativity & 3.92 & .99 & 1.00 & 5.00 \\
\hline Algorithmic thinking & 3.66 & .94 & 1.00 & 5.00 \\
\hline Cooperativity & 3.97 & 1.05 & 1.00 & 5.00 \\
\hline Critical thinking & 2.81 & 1.09 & 1.00 & 5.00 \\
\hline Problem solving & 3.73 & .93 & 1.00 & 5.00 \\
\hline
\end{tabular}


When Table 2 is examined, it is seen that the cooperativity sub-scale mean scores of the students are higher than the other sub-scales. Their mean scores for the critical thinking sub-scale are the lowest. Students' overall computational thinking skills level is medium.

\section{The Game Types That Students Play}

In order to find out the types of games that students play, the percentages and frequency values for the Questionnaire for Type of Games Played with Digital Tools were shown in Table 3.

Table 3. Breakdown of the Types of Games Students Play

\begin{tabular}{lcc}
\hline Categories & $\mathbf{f}$ & $\%$ \\
\hline Dress Up / Make Up Games & 41 & 20.3 \\
\hline Information / Logic Games & 37 & 18.3 \\
\hline Car / Racing / Sports Games & 36 & 17.8 \\
\hline Strategy / War / Adventure Games & 28 & 13.9 \\
\hline Educational Games & 19 & 9.4 \\
\hline Build & 15 & 7.4 \\
\hline Multiplayer Games & 11 & 5.4 \\
\hline Card Games & 9 & 4.5 \\
\hline Simulation Games & 6 & 3.0 \\
\hline
\end{tabular}

When the breakdown of the types of games students play are examined, it seems that the most frequently played game category is "Dress up/Make Up" games with a rate of $20 \%$; whereas it is "Simulation" games that constitute the least played by the students with a rate of $3 \%$.

\section{Students Computational Thinking Skills Level Based on the Types of Games They Play}

The Kruskal Wallis test scores of the students regarding the creativity sub-scale of the computational thinking skills scale are given in Table 4; the scores for the algorithmic thinking sub-scale are given in Table 5; the scores on the cooperativity sub-scale are given in Table 6; the scores with respect to the critical thinking level sub-scale are given in Table 7 and the scores regarding problem solving sub-scale are given in Table 8.

Table 4. Kruskal Wallis Test Result of the Creativity Levels of the Students Based on the Breakdown of the Types of Games They Play

\begin{tabular}{|c|c|c|c|c|c|}
\hline Subscales & Game Types & Mean Rank & df & $x^{2}$ & $\mathbf{p}$ \\
\hline \multirow{9}{*}{ Creativity } & Build & 78.57 & \multirow{9}{*}{8} & \multirow{9}{*}{15.448} & \multirow{9}{*}{.051} \\
\hline & Card Games & 66.17 & & & \\
\hline & Car / Racing / Sports Games & 91.97 & & & \\
\hline & Educational Games & 132.63 & & & \\
\hline & Simulation Games & 103.17 & & & \\
\hline & Strategy / War / Adventure Games & 93.38 & & & \\
\hline & Dress Up / Make Up Games & 101.89 & & & \\
\hline & Information / Logic Games & 117.46 & & & \\
\hline & Multiplayer Games & 103.73 & & & \\
\hline
\end{tabular}


Looking at Table 4, it is seen that creativity levels of students do not display a significant difference based on the type of game they play $\left(x^{2}(8)=15.448, p \geq .05\right)$. Although there appears to be no significant difference, when the means are considered, it can be seen that students who play "Educational Games" have the highest mean which is followed by students playing "Information/Logic Games" and students playing "Multiplayer Games".

Table 5. Kruskal Wallis Test Result of the Algorithmic Thinking Skill Levels of the Students Based on the Breakdown of the Types of Games They Play

\begin{tabular}{|c|c|c|c|c|c|}
\hline Subscales & Game Types & Mean Rank & df & $x^{2}$ & $\mathbf{p}$ \\
\hline \multirow{9}{*}{$\begin{array}{l}\text { Algorithmic } \\
\text { thinking }\end{array}$} & Build & 98.63 & \multirow{9}{*}{8} & \multirow{9}{*}{26.903} & \multirow{9}{*}{.001} \\
\hline & Card Games & 63.28 & & & \\
\hline & Car / Racing / Sports Games & 76.90 & & & \\
\hline & Educational Games & 127.74 & & & \\
\hline & Simulation Games & 106.17 & & & \\
\hline & $\begin{array}{l}\text { Strategy / War / Adventure } \\
\text { Games }\end{array}$ & 88.50 & & & \\
\hline & Dress Up / Make Up Games & 96.27 & & & \\
\hline & Information / Logic Games & 131.03 & & & \\
\hline & Multiplayer Games & 122.59 & & & \\
\hline
\end{tabular}

Looking at Table 5 , it is seen that students' algorithmic thinking levels show a statistically significant variance based on the type of game they play $\left(x^{2}(8)=26.903, p<.05\right)$.

This finding indicates that types of games have different effects on the algorithmic thinking levels. When the mean scores of the groups are considered, it is seen that students playing "Information/Logic Games" have the highest algorithmic thinking levels, and they are followed by students playing "Educational Games" and students playing "Multiplayer Games".

Table 6. Kruskal Wallis Test Result of the Cooperativity Levels of the Students Based on the Breakdown of the Types of Games They Play

\begin{tabular}{|c|c|c|c|c|c|}
\hline Subscales & Game Types & Mean Rank & df & $x^{2}$ & $\mathbf{p}$ \\
\hline \multirow{9}{*}{ Cooperativity } & Build & 69.23 & \multirow{9}{*}{8} & \multirow{9}{*}{38.417} & \multirow{9}{*}{.000} \\
\hline & Card Games & 84.50 & & & \\
\hline & Car / Racing / Sports Games & 74.25 & & & \\
\hline & Educational Games & 114.97 & & & \\
\hline & Simulation Games & 125.50 & & & \\
\hline & Strategy / War / Adventure Games & 79.07 & & & \\
\hline & Dress Up / Make Up Games & 110.17 & & & \\
\hline & Information / Logic Games & 141.82 & & & \\
\hline & Multiplayer Games & 101.36 & & & \\
\hline
\end{tabular}

Table 6 demonstrates that the cooperativity levels of students show a statistically significant difference based on the type of game they play $\left(x^{2}(8)=38.417, p<.05\right)$. When the averages of 
the groups are considered, it can be seen that students playing "Information/Logic Games" have the highest cooperativity levels.

Table 7. Kruskal Wallis Test Result of the Critical Thinking Levels of the Students Based on the Breakdown of the Types of Games They Play

\begin{tabular}{|c|c|c|c|c|c|}
\hline Subscales & Game Types & Mean Rank & df & $x^{2}$ & $\mathbf{p}$ \\
\hline \multirow{9}{*}{ Critical thinking } & Build & 58.53 & \multirow{9}{*}{8} & \multirow{9}{*}{12.314} & \multirow{9}{*}{.138} \\
\hline & Card Games & 96.17 & & & \\
\hline & Car / Racing / Sports Games & 111.64 & & & \\
\hline & Educational Games & 89.21 & & & \\
\hline & Simulation Games & 127.25 & & & \\
\hline & Strategy / War / Adventure Games & 110.04 & & & \\
\hline & Dress Up / Make Up Games & 107.02 & & & \\
\hline & Information / Logic Games & 99.50 & & & \\
\hline & Multiplayer Games & 102.86 & & & \\
\hline
\end{tabular}

Table 7 shows that students' critical thinking levels do not show a statistically significant difference based on the type of game they play $\left(x^{2}(8)=12.314, p>.05\right)$.

When the mean scores of the groups are considered, it is obvious that students playing "Information/Logic Games" have the highest cooperativity levels. Although there is no significant difference, when the averages are considered, it is seen that students who play "Simulation Games" have the highest critical thinking level.

Table 8. Kruskal Wallis Test Result of the Problem Solving Levels of the Students Based on the Breakdown of the Types of Games They Play

\begin{tabular}{|c|c|c|c|c|c|}
\hline Subscales & Game Types & Mean Rank & df & $x^{2}$ & $\mathbf{p}$ \\
\hline \multirow{9}{*}{ Problem solving } & Build & 90.37 & \multirow{9}{*}{8} & \multirow{9}{*}{27.311} & \multirow{9}{*}{.001} \\
\hline & Card Games & 72.28 & & & \\
\hline & Car / Racing / Sports Games & 80.26 & & & \\
\hline & Educational Games & 131.74 & & & \\
\hline & Simulation Games & 98.25 & & & \\
\hline & Strategy / War / Adventure Games & 87.80 & & & \\
\hline & Dress Up / Make Up Games & 92.80 & & & \\
\hline & Information / Logic Games & 133.03 & & & \\
\hline & Multiplayer Games & 120.86 & & & \\
\hline
\end{tabular}

When Table 8 is examined, it is seen that students' cooperativity levels vary based on the type of game they play $\left(x^{2}(8)=27.311, p<.05\right)$. The means of the groups demonstrate that students playing "Information/Logic Games" have the highest problem solving levels compared to other groups. 


\section{Result and Discussion}

This study aimed at identifying whether students' computational thinking skills differ depending on the type of digital game that secondary school students play. The results show that students' scores from cooperativity sub-scale is higher than other sub-scales, while their score from critical thinking sub-scale is the lowest. It is believed that games that motivate students to develop computational thinking skills more. In their study, Kazimoglu, Kiernan, Bacon and MacKinnon (2012) examined games designed to develop computational thinking skills and programming activities. It was found that the inclusion of such activities as bringing pieces together, examining different cases and possibilities and evaluating the results that occur had positive effects on the development of the computational skills of students. In addition to that, it is asserted that the activities made students to participate willingly.

There appears to be no statistically significant difference with respect to the creativity and critical thinking levels of students based on the type of game they play. On the other hand, students' algorithmic thinking, cooperativity and problem solving levels display a statistically significant difference based on the type of game that they play. In a game system designed considering the nature of constructivist learning, giving problems, producing and implementing solutions with algorithmic steps in order to overcome the obstacles are important in terms of the development of computational thinking (Chen, Wigand, \& Nilan, 1999). In addition, it is claimed that since games enable students to comprehend a complex system either by themselves or collaboratively, enables them to look into the solutions they find in a critical manner and enables them to determine a logical strategy using analytical thinking in the process of problem solving, they can support the development of various thinking skills (Boyle, Connolly, \& Hainey, 2011; Jeffries, 2005; Rivers \& Vockell, 1987). Therefore, games of high quality could help develop skills with regards to computational thinking. Besides, games have significant effects on developing research strategies and self-learning skills (Pinto, 1999).

This study demonstrated that students' playing "Educational Games" have the highest creativity level; while students playing "Information/Logic Games" have the highest algorithmic thinking, cooperativity and problem solving levels and students playing "Simulation Games" have the highest critical thinking levels. Studies emphasize the importance of problem solving in computational thinking. In their study, Liu, Cheng, and Huang, (2011) found that simulation games are important in developing students' problem solving skills. Drawing this result, it is indicated that such features of simulation games as giving instant feedback, enabling the analysis of the activity diaries, engaging students in trial and error, motivating to implement reasoning strategies and offering experiences with its algorithmic structure are efficient. On the other hand, some complex games such as the simulation games appear to give students a cognitive burden, increases their anxiety levels and causes negative results in acquiring certain skills (Yamen, Nerdel, \& Bayrhuber, 2008).

The study was carried out in a school environment so, at this point, it is possible that students did not give genuine answers. Considering this limitation of the study, it is suggested that further studies should be repeated in environments outside the school or mixed methods should be used. This study examined the relationships between digital game preferences of secondary school students and their computational thinking skills. In future studies, an in-depth examination of in which ways the type of game preferred effect computational thinking could be made. On the other hand, in the current study, it was found that students' critical thinking skills level was low. To improve that, the role of the game types could be examined with experimental studies. 


\section{References}

Anderson, C. A. \& Bushman, B. J. (2001). Effects of violent video games on aggressive behavior, aggressive cognition, aggressive affect, physiological arousal, and prosocial behavior: A meta-analytic review of the scientific literature. Psychological Science, 12(5), 353-359.

Barr, V. \& Stephenson, C. (2011). Bringing computational thinking to K-12: what is Involved and what is the role of the computer science education community? ACM Inroads, 2(1), 4854.

Boyle, E., Connolly, T. M., \& Hainey, T. (2011). The role of psychology in understanding the impact of computer games. Entertainment Computing, 2(2), 69-74.

Brennan, K. \& Resnick, M. (2012). New frameworks for studying and assessing the development of computational thinking. Proceedings of the April 2012 annual meeting of the American Educational Research Association, Vancouver, Canada (pp. 1-25).

Chen, H., Wigand, R. T., \& Nilan, M. S. (1999). Optimal experience of web activities. Computers in Human Behavior, 15(5), 585-608.

Connolly, T. M., Boyle, E. A., MacArthur, E., Hainey, T., \& Boyle, J. M. (2012). A systematic literature review of empirical evidence on computer games and serious games. Computers \& Education, 59(2), 661-686.

Connolly, T., Stansfield, M. H., \& Hainey, T. (2008). Development of a general framework for evaluating games-based learning. Proceedings of the 2nd European conference on games-based learning (pp. 105-114). Universitat Oberta de Catalunya Barcelona, Spain.

De Freitas, S. (2006). Learning in immersive worlds. London: Joint Information Systems Committee.

Ferguson, C. J. (2007). The good, the bad and the ugly: A meta-analytic review of positive and negative effects of violent video games. Psychiatric Quarterly, 78(4), 309-316.

Griffiths, M. D., Davies, M. N., \& Chappell, D. (2004). Demographic factors and playing variables in online computer gaming. CyberPsychology \& Behavior, 7(4), 479-487.

Grover, S. \& Pea, R. (2013). Computational thinking in k-12 a review of the state of the field. Educational Researcher, 42(1), 38-43.

Hoffman, D. L. \& Novak, T. P. (1996). Marketing in hypermedia computer-mediated environments: Conceptual foundations. The Journal of Marketing, 60(3), 50-68.

ISTE (2015). CT Leadership toolkit. Retrieved on 19 January 2017 from http://www.iste.org/ docs/ct-documents/ctleadershipt-toolkit.pdf?sfvrsn=4.

Jeffries, P. R. (2005). A framework for designing, implementing, and evaluating: Simulations used as teaching strategies in nursing. Nursing Education Perspectives, 26(2), 96-103.

Karasar, N. (2015). Scientific research method. Ankara: Nobel.

Kazimoglu, C., Kiernan, M., Bacon, L., \& MacKinnon, L. (2012). Learning programming at the computational thinking level via digital game-play. Procedia Computer Science, 9, 522531. 
Kim, B., Park, H., \& Baek, Y. (2009). Not just fun, but serious strategies: Using meta-cognitive strategies in game-based learning. Computers \& Education, 52(4), 800-810.

Korkmaz, O., Cakir, R., \& Ozden, M. Y. (2015). Computational thinking levels scale (CTLS) adaptation for secondary school level. Gazi Journal of Educational Science, 1(2), 143162.

Lee, C. Y. \& Chen, M. P. (2009). A computer game as a context for non-routine mathematical problem solving: The effects of type of question prompt and level of prior knowledge. Computers \& Education, 52(3), 530-542.

Liu, C. C., Cheng, Y. B., \& Huang, C. W. (2011). The effect of simulation games on the learning of computational problem solving. Computers \& Education, 57(3), 1907-1918.

Ogletree, S. M. \& Drake, R. (2007). College students' video game participation and perceptions: Gender differences and implications. Sex Roles, 56(7-8), 537-542.

Papastergiou, M. (2009). Digital game-based learning in high school computer science education: Impact on educational effectiveness and student motivation. Computers \& Education, 52(1), 1-12.

Pinto, P. R. (1999). A computer simulation designed for problem-based learning. Medical Education, 33(1), 47-54.

Rivers, R. H. \& Vockell, E. (1987). Computer simulations to stimulate scientific problem solving. Journal of Research in Science Teaching, 24(5), 403-415.

Shih, J. L., Shih, B. J., Shih, C. C., Su, H. Y., \& Chuang, C. W. (2010). The influence of collaboration styles to children's cognitive performance in digital problem-solving game "William Adventure": A comparative case study. Computers \& Education, 55(3), 982-993.

Subrahmanyam, K. \& Greenfield, P. M. (1994). Effect of video game practice on spatial skills in girls and boys. Journal of Applied Developmental Psychology, 15(1), 13-32.

Tan, J. \& Biswas, G. (2007). Simulation-based game learning environments: Building and sustaining a fish tank. In Digital Game and Intelligent Toy Enhanced Learning, 2007. DIGITEL'O7. The First IEEE International Workshop on (pp. 73-80). IEEE.

The National Research Council (NRC) (2012). A framework for K-12 science education: Practices, crosscutting concepts, and core ideas. The National Academies Press.

Wing, J. M. (2006). Computational thinking. Communications of the ACM, 49(3), 33-35.

Yaman, M., Nerdel, C., \& Bayrhuber, H. (2008). The effects of instructional support and learner interests when learning using computer simulations. Computers \& Education, 51(4), 1784-1794.

Correspondence: Ramazan Yilmaz, Assistant Professor, Department of Computer Education and Instructional Technologies, Faculty of Education, Bartin University, Bartin, Turkey. 